\title{
The Regional Resource Potential as a Factor in Ensuring Economic Security at the Meso-Level
}

\author{
Liu Chunguang ${ }^{1}$ J.R. Mezentseva ${ }^{2, *}$ G.E. Krokhicheva ${ }^{2}$ E.L. Arkhipov ${ }^{2}$ \\ O.A. Alekseeva ${ }^{3}$
}

\author{
${ }^{1}$ Shandong Jiatong University, Jinan City, Shandong Province, China \\ ${ }^{2}$ Don State Technical University, Rostov-on-Don, Russia \\ ${ }^{3}$ North Caucasus Federal University, Stavropol, Russia \\ *Corresponding author.Email: mezentseva.y.r@mail.ru
}

\begin{abstract}
The article discusses the organizational and methodological foundations of ensuring economic security at the meso-level and its relationship with the resource potential of the region. The role of the resource potential in socio-economic development of the region is considered. The object of the study is associated with various components of the resource potential of the Rostov region and its economic security. The authors studied the characteristics of the Rostov region in two sections: determining the level of economic security at the mesolevel and assessing its resource potential with establishing the relationship between them on the basis of available official statistical data. The findings on the economic security level in the region are not final. This underlines the necessity for further scientific development, which will logically continue the methods for assessing the economic security of the Russian regions considered in the article.
\end{abstract}

Keywords: economic security, region, potential, resource potential, analysis, assessment, threats to economic

security, assessment methodology

\section{INTRODUCTION}

The problems associated with the economic security of any order system do not lose their significance under the conditions of a dynamically changing external environment and often poorly predicted influence of various factors [1]. Immediately after the Economic Security Strategy of the Russian Federation until 2030 adoption in March 2017, the issue of the need to improve approaches to strengthening security at the level of constituent entities of the Russian Federation became relevant [2-7].

Economic security can be considered at several levels: international (mega-level), economic security of a country (or national) (macro-level), economic security of a region / industry (meso-level), an economic entity and an individual (micro-level). In this article we will consider the meso-level of economic security as one of the most important, since "the economic security of the state cannot be achieved in the absence of economic security of its constituent units and territories" [8].

One of the possible key factors of influence on the level of economic security in any context, including regional one, is the intensification of the existing resource potential use. This is a consequence of the fact that a significant part of the rights and the corresponding part of the obligations are transferred to the regions, the important task of implementing the socio-economic policy of Russia and achieving the strategic development goals set by the state is entrusted to the regions [9-10].
The independence of the regions in pursuing economic policy and implementing the economic security strategy is based on a wide resource base, which makes the problems of increasing the level of resource potential and its effective use in order to accelerate the socio-economic development of the regions, increasing their investment attractiveness and ensuring their economic security in a single national system very topical.

The study of a significant number of works devoted to the problems of regional economic security revealed that the issues of the region's resource potential influence on the level of its economic security remain insufficiently studied. From this point of view, the study of the regional resource potential as a factor in ensuring economic security at the meso-level is of strategic importance.

The purpose of this article is to study, generalize and systematize certain aspects of the regional economic security indicators' relationship with the level of its resource potential, as well as the resource potential analysis of a particular region.

Achieving this goal involves setting and solving the following tasks:

- to generalize and systematize the existing provisions characterizing the nature and specificity of the resource potential as a factor for ensuring economic security;

to analyze the economic security level of a particular region of the Russian Federation and evaluate its resource potential.

Summarizing the abovesaid, the authors propose that the economic security of the state cannot be achieved in the 
absence of economic security of its entities and territories that have a certain level of effective resource potential.

\section{THEORETICAL AND METHODOLOGICAL RESEARCH BASIS}

In conditions when the national economy is undergoing sanctions, its economic growth is slowing down. One of the positive impact possible directions on the current situation is the intensification of the existing resource potential use of the state and the constituent entities of the federation. The economy effective development in conditions of resource scarcity suggests that the economic activity should be based on the most rational use of existing production, personnel and scientific capabilities. This trend is superimposed on the processes of innovative modernization in the Russian Federation, focused on the latest technologies' use in all the economy sectors [11].

Having summarized the existing approaches to the nature and resource potential specifics, they can be understood as a factor in ensuring economic security.

The disclosure of the term "resource potential" involves its constituent concepts' clarification. "Resort" is a derivative of the word "resource". According to the large encyclopedic dictionary, the term "resources" (French "ressources") means "the means, reserves, opportunities, sources of something" [12]. The content of the term "potential" originates from the Latin word "potentia" and in translation means "strength, power".

There are several basic approaches to the term definition "potential" in the scientific economic literature which differ in the authors' view of its structure and its constituent elements' relationship [13-15]. The work on the effective use of all the resource potential components should be structured and optimized as much as possible for qualitive work in the region.

The problem of forming the methodological foundations for assessing the effectiveness of the territory economic reserves' use, including meso level, was considered in a large number of works both by foreign and Russian scientists. The analysis of these works allows to identify the approaches to calculating the key indicators based on:

- a relative indicator / group of indicators, which in the end, as a rule, provides the calculation of an index or group of indices;

- absolute indicator.

1. The resource potential assessment by a single integrated indicator.

Several works should be distinguished in this case. The methodology developed by G. E. Mekush suggests calculating the resource potential of the territory (the final comprehensive indicator) on the basis of three groups indicators depending on a certain type of resources [16]. In the methodology developed by E. A. Bessonova, it is proposed to form a comprehensive indicator of the region's resource potential level based on the four factors blocks [14].
S. S. Galazova based her view on the problem by calculating the indicator according to seven particular criteria affecting the territorial socio-economic development [17].

2. The resource potential assessmentof based on identified factors (elements).

O. A. Lomovtseva's approach, which suggests conducting research on the totality of human, technological, natural, organizational, informational, institutional factors should be noted in this group of techniques. The considered set of material and intangible resources of the regional economic potential is presented by the author in graphic form [18].

The assessment of the economic potential of the region's innovative development proposed by $\mathrm{Yu}$. V. is based on the idea of analyzing the resource supply indicators [19].

3 . The resource potential assessment of the territory on the basis of a point scale.

The basis of this approach is the principle of assigning points to a certain group of resources involved, depending on their importance in business processes. It should be noted that such a toolkit was developed and used by the Russian researchers back in the Soviet economy.

The analysis results of the various tools for assessing the resource potential makes it possible to draw a number of conclusions:

- there is no universal (single) methodological approach to the territorial resource potential study, which emphasizes the complex debatable nature of this issue;

- most of the existing approaches suggest the equivalent development of the resource potential elements, which is impossible due to the presence of individual characteristics in the regions both in natural conditions and in the established industrial specialization;

- regardless of the analysis methodology, the result is one or a group of indicators, the assessment of which is often subjective.

The availability of proper quality objective information about the resource potential assessment in the context of the elements forming it, allows to effectively manage them at all stages of their formation, development, updating and use. The economic security level depends on the region's resources provision at an optimal level and in a rational structure. This influence is carried out through the complex interaction of each type of resource.

The region economic security measurement and assessment is carried out on the key indicators analysis basis, the growth rates assessment at the regional level, forecasting their changes and dynamics; expert assessment is carried out to describe the quantitative and qualitative characteristics of the investigated processes; scenario analysis and processing; methods of optimization, pattern recognition, game-theoretic methods of multivariate statistical analysis, etc. are used [20-23]. 


\section{THE RESEARCH AND DISCUSSION RESULTS}

\subsection{The Rostov Region Economic Security Level's Analysis}

The economic security of Russia consists of the economic security of its regions. When considering the economic security level of the constituent entities in the Russian Federation, Rostov Region is of particular interest as a promising subject of economic development in the South of Russia. There are external (primarily foreign policy and foreign economic factors) in the region as well as internal threats to its economic well-being, conditions and the factors dangerous for the region's economy, as shown in Figure 1.

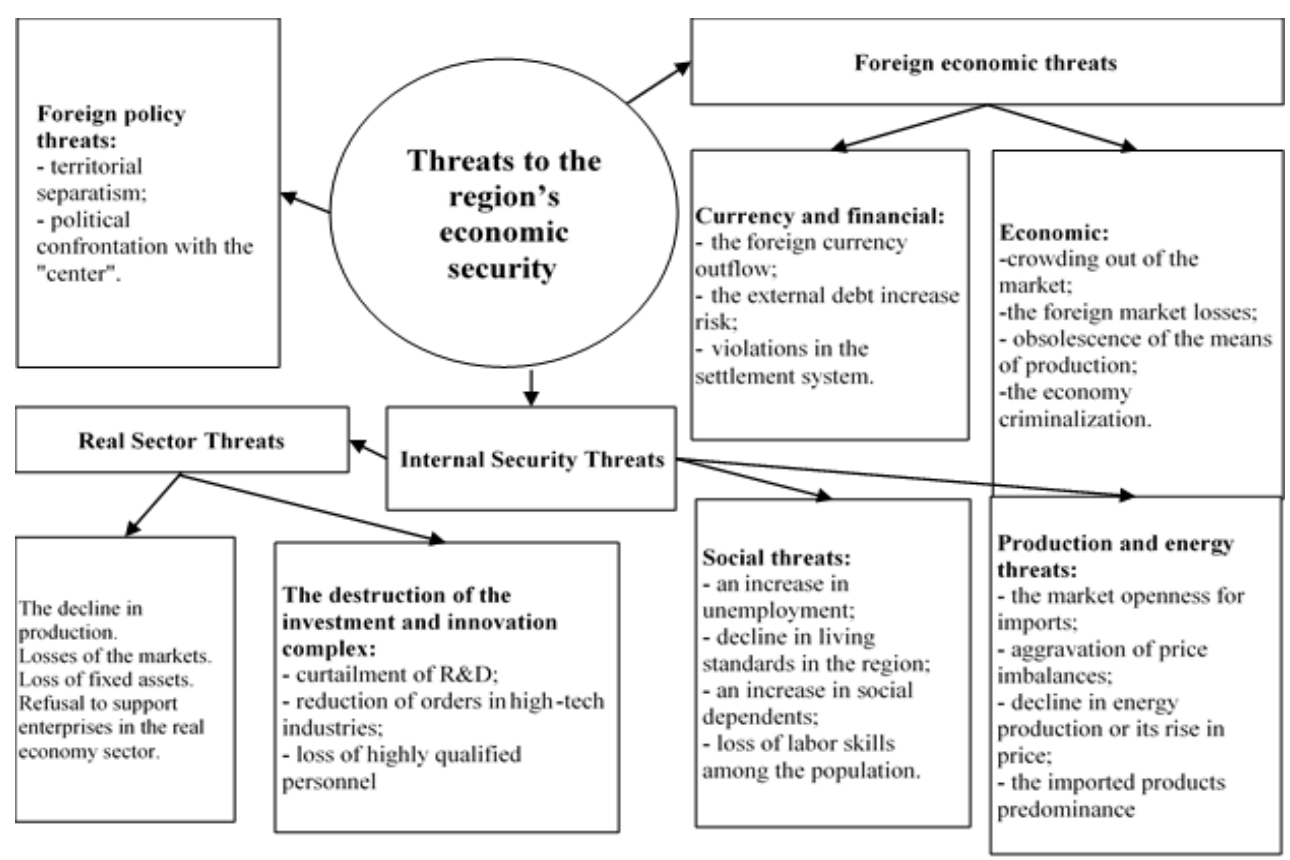

Figure 1 Classification of threats to regional economic security [24], supplemented by the authors

The economic security strategy of the Rostov Region consists in determining the nature of external and internal threats to its economic well-being, in creating a data bank on conditions and factors posing danger to the vital economic interests of the region's population, market entities and creating an effective mechanism for government authorities to respond to the economic security threats.

As the basis for the comparative characteristics of the region's economic indicators with threshold values, we use the Table of indicators grouped in Table 1, formed on the open data basis [25-27].

The list of threshold values may include a different set of indicators [28]. With their help, it is possible to determine the maximum level of the region and individual industries economic development deviation parameters. It is also possible to predict a threat and respond to it in time using threshold values.

The Rostov Region economic security indicators analysis shows that in the "Economic Development" part, most of the calculated indicators are better than the threshold value of the indicators.

The indicators calculations results for projections, reflecting social, innovative and environmental development, testify to the problems of the region in these areas.
The region's special problems are associated with innovative development - not one of the indicators has exceeded the threshold value, which indicates the region's unsatisfactory policy in terms of innovation.

The indicators of the section "Environmental Development" indicate significant emissions of pollutants into the atmosphere and discharges into wastewater, negatively affecting the region's environment.

To enhance the economic security of the Rostov region, starting in 2015, a favorable platform for the development of small and medium-sized enterprises, which contributes to the establishment of the investment climate in the region and the attraction of financial resources of small investors, has been created. To increase the effectiveness of social protection mechanisms, the Rostov Region Government is taking actions to apply a set of measures affecting the increase of inter-industry and territorial mobility of the region's residents.

Thus, the Rostov Region economic security indicators analysis shows that the regional leadership is supposed to pay more attention to social policy, the development of innovative activities and environmental protection, it is necessary to develop a system of measures to prevent the threats to regional security. The region provides a large number of measures to ensure economic security. 
Table 1 The region's economic security indicators

\begin{tabular}{|c|c|c|c|}
\hline Indicator name & $\begin{array}{l}\text { Threshold } \\
\text { value }\end{array}$ & 2018 fact & $\begin{array}{c}\text { Conformity/ } \\
\text { threshold } \\
\text { mismatch }\end{array}$ \\
\hline \multicolumn{4}{|l|}{ Economic development } \\
\hline Gross regional product, billion rubles & - & 1424,40 & \\
\hline Gross regional product per capita, thousand rubles & $\geq 413,2$ & 338,97 & - \\
\hline Annual inflation rate, $\%$ & $\leq 6$ & 4,30 & + \\
\hline Investments in fixed assets, billion rubles & - & 252,90 & - \\
\hline Fixed capital investment, \% of gross regional product & $\geq 25$ & 17,75 & \\
\hline The industrial enterprises fixed assets depreciation degree, \% & $\leq 50$ & 43,50 & + \\
\hline The balance of foreign trade balance, $\%$ of gross regional product & $\geq-4$ и $\leq 8$ & 2,70 & + \\
\hline Balance of the consolidated budget of the region, \% of gross regional product & $\geq-3$ и $\leq 4$ & $-1,25$ & + \\
\hline \multicolumn{4}{|l|}{ Social development } \\
\hline The ratio of per capita income to the subsistence level, times & $\geq 3,5$ & 2,70 & - \\
\hline The ratio of average pension to average wage, $\%$ & $\geq 40$ & 55,00 & + \\
\hline Unemployment rate according to the methodology of the International Labor Organization (ILO), \% & $\leq 6$ & 5,10 & + \\
\hline Life expectancy at birth, years & $\geq 80$ & 73,00 & - \\
\hline Housing size per inhabitant, $\mathrm{m}^{2}$ & $\geq 25$ & 25,80 & + \\
\hline Funds for health care, education and social policy, \% of gross regional product & $\geq 15$ & 10,70 & - \\
\hline \multicolumn{4}{|l|}{ Innovative development } \\
\hline The share of shipped innovative products in all shipped industrial products, \% & $\geq 30$ & 8,40 & - \\
\hline $\begin{array}{l}\text { The number of people engaged in research and development per } 10 \text { thousand of the employed } \\
\text { population }\end{array}$ & $\geq 120$ & 84,00 & - \\
\hline Internal costs of research and development, \% of gross regional product & $\geq 2,2$ & 1,20 & - \\
\hline $\begin{array}{l}\text { The intensity of the technological innovation cost (the ratio of the technological innovation cost to } \\
\text { the volume of output), \% }\end{array}$ & $\geq 3,2$ & 1,38 & - \\
\hline The number of applications for invention and utility models per 10 thousand population & $\geq 15$ & 1,68 & - \\
\hline \multicolumn{4}{|l|}{ Environmental development } \\
\hline Discharge of polluted wastewater, thousand $\mathrm{m}^{3} / \mathrm{km}^{2}$ & $\leq 0,3$ & 2,36 & - \\
\hline Air pollutant emissions from stationary sources, $\mathrm{t} / \mathrm{km}^{2}$ & $\leq 0,5$ & 1,63 & - \\
\hline Reforestation (percentage of reforestation), \% & $\geq 0,15$ & 0,90 & + \\
\hline
\end{tabular}

The development of territorial-sectoral, agricultural, innovative and other anti-crisis programs, with their successful implementation, will contribute to the favorable development of various industries.

\subsection{Assessment of the Region Resource Potential}

Rostov region is one of the most stable regions of Russia. In all periods of its history, characterized by high rates of economic development and business activity, it has been and remains a region with a wealth of resource potential. The region has a favorable territorial, geopolitical, economic-geographical and transport-logistical position, including for international transit.

The resource potential of the region through its following main components is characterized by:

- resource and raw materials potential;

- population and labor resources;

- production potential;

- financial potential;

- scientific and technical;

- export potential;

- tourist potential.

The resource potential of the region can be estimated by the use of the information contained in open analytical studies and forecasts [27, 29-31].
1. Resource and raw materials potential. It is defined as the totality of all types of natural resources that can be used. Since the composition, magnitude of the potential, and significance of individual types of resources are not the same and can change over time, their assessment is always relative.

The main strategic resource of this type and the main competitive advantage of the region is 8.5 million hectares of agricultural land. With such a land fund, the region is able to be a leading supplier in the agricultural and food markets of the Russian Federation.

The region has the resource potential of fuel and energy, construction, heat insulation, metallurgical, agrochemical and ore raw materials. The mineral and raw material potential of the Rostov Region is also great: these are nonmetallic minerals, which are the basis for the building materials and the construction industry production development. The region also has the prerequisites for expanding the resource potential of scarce types of raw materials: such as cement, raw materials for the production of mineral wool, agrochemical, siliceous, glass, sorbent and pigment. A significant part of the region is oil and gas. Explored gas reserves amount to 36.85 billion $\mathrm{m} 3$, and previously estimated -22.48 billion $\mathrm{m} 3$.

We have listed only some of the main components of the region's resource and raw materials potential, which allow us to assert its enormous size, the implementation of which will significantly increase the production volumes, which in 
turn will have a positive impact on the region's economic security growth.

2. Production potential is one of the main objects of the regional development strategic analysis, including the real volume of products that can be produced with full use of available resources. To date, there is no consensus on the production potential category definition, on its structure and, as a consequence, on assessment methods. In this regard, we dwell on the production potential main components' characteristics, tied to the region.

The production potential structural analysis of the region made it possible to identify the industrial potential, agricultural potential, the potential of the construction industry and others, that is, the potentials of industries related to the manufacturing sector.

The analysis of the basic dynamic and structural parameters of industrial development in the Rostov Region indicates an acceleration in industrial production. Despite the positive dynamics of manufacturing in the region, the potential in this direction has not been fully realized. In particular, the Rostov region takes the 6th place in the country by population, but the 12th place in terms of gross regional product among the Russian Federation constituent units, the largest industrial enterprises are localized in the region. To ensure the regional leadership, it is necessary to ensure the quality use of the considered growth reserve.

The Rostov region is one of the largest agricultural centers in Russia with a high level of agriculture and food processing industry development. According to the results of 2018, the Rostov Region occupies a leading position in Russia in the following areas: gross harvest of winter and spring wheat; gross harvest of seeds and oilseeds; production of refined vegetable oil; egg production; milk production, etc. Agriculture is one of the Rostov region economy key sectors, accounting for 14.2 percent in the structure of its gross regional product.

The Rostov Region construction sector development key indicators dynamics shows that the region is among the leaders in Russia.

3. The population and labor resources.

Population is the most important demographic indicator that determines the economic importance, labor potential and consumer capacity of the regional market. The human capital of the Rostov region is a powerful resource for the development of the regional economy. In terms of population density, which is on average 5.1 times higher than the average population density of the Russian Federation, the Rostov region takes the 5th place among the state entities [32-34]. The dynamics of the Rostov region resident population in 2011 - 2018 is presented in Table 2. In terms of the resident population, the region steadily occupies the 6th place in Russia and the 2nd place in the Southern Federal District, giving the way to the Krasnodar Territory. The able-bodied population is $58 \%$, which is important when calculating the tax potential of the region. The resulting indicators characterizing the current demographic situation in the Rostov region are presented in Table 3.

Table 2 The Dynamics of the Rostov region resident population [29], supplemented by the author

\begin{tabular}{|l|l|l|l|l|l|l|l|l|l|}
\hline \multicolumn{1}{|c|}{ Parameter Name } & \multicolumn{1}{|c|}{$\mathbf{2 0 1 1}$} & $\mathbf{2 0 1 2}$ & $\mathbf{2 0 1 3}$ & $\mathbf{2 0 1 4}$ & $\mathbf{2 0 1 5}$ & $\mathbf{2 0 1 6}$ & $\mathbf{2 0 1 7}$ & $\mathbf{2 0 1 8}$ \\
\hline Number of the resident population on January 1 (thousand people) \\
\hline Rostov region & 4275,2 & 4260,5 & 4254,6 & 4245,5 & 4242,1 & 4236,0 & 4231,4 & 4220,5 \\
\hline RO share in the Russian Federation,\% & 2,99 & 2,98 & 2,97 & 2,96 & 2,90 & 2,89 & 2,88 & 2,87 \\
\hline RO place in the Russian Federation & $6-\mathrm{e}$ & 6 -e & 6 -e & 6 -e & 6 -e & 6 -e & 6 -e & 6 -e \\
\hline
\end{tabular}

Table 3 The Dynamics of key indicators of demographic development of the Rostov region [29], supplemented by the author

\begin{tabular}{|c|c|c|c|c|c|c|c|c|}
\hline Parameter Name & 2011 & 2012 & 2013 & 2014 & 2015 & 2016 & 2017 & 2018 \\
\hline \multicolumn{9}{|l|}{ Total fertility rate } \\
\hline Rostov region & 1,39 & 1,51 & 1,52 & 1,61 & 1,63 & 1,60 & 1,46 & 1,42 \\
\hline RO place in the Russian Federation & $74-\mathrm{e}$ & 72-e & $75-\mathrm{e}$ & 68-e & $72-\mathrm{e}$ & 71-e & $72-\mathrm{e}$ & no data \\
\hline \multicolumn{9}{|l|}{ Coefficient of natural population growth } \\
\hline Rostov region & $-3,4$ & $-2,3$ & $-2,1$ & $-2,0$ & $-1,8$ & $-2,3$ & $-3,1$ & $-3,8$ \\
\hline RO place in the Russian Federation & $58-\mathrm{e}$ & $56-\mathrm{e}$ & $55-56-e$ & 55-e & $55-\mathrm{e}$ & $56-57-\mathrm{e}$ & $54-55-e$ & no data \\
\hline \multicolumn{9}{|l|}{ Migration growth (person) } \\
\hline Rostov region & -259 & 3633 & -141 & 4896 & 1602 & 5035 & 1907 & -2400 \\
\hline RO place in the Russian Federation & $43-\mathrm{e}$ & $19-\mathrm{e}$ & $35-\mathrm{e}$ & 15-e & $24-\mathrm{e}$ & $16-\mathrm{e}$ & $17-\mathrm{e}$ & no data \\
\hline
\end{tabular}

The demographic situation in the Rostov region is a reflection of socio-economic trends, as well as the demographic processes of the previous decades, which took place in the region in particular and in the Russian Federation in general [33].

The current state of the population social development sphere is assessed with a system of relative indicators:

1) The average unemployment rate for the year (percent). According to this indicator, the Rostov region takes the 5th place among all the subjects of the Russian Federation (according to the 2017 data for 2017, it occupies the 45th- 46th place) [32].

2) Cash income on average per capita (rubles). This indicator also puts the region in the 40th to 50th place in Russia (according to the data for 2017 - 49th place) [25].

3) The proportion of the population with incomes below the subsistence level (percent). This indicator has a higher level, according to the data for 2017 - 35th - 36th place [25] 4) The level of the population education at an economically active age is sufficient. This indicator is high. So, per 1000 people, 300 have secondary specialized education, 400 have a secondary general education, 87 have an incomplete 
secondary education, 190 have a higher education, and 12 have an incomplete higher education [29].

5) The share of the highly skilled workers in the total number of the skilled workers in 2017 amounted to $28.1 \%$. This indicates the need to increase the level of professional training of the able-bodied population, which is one of the fundamental moments in the implementation of the problem of improving the quality of production and GRP growth [29].

The level of indicators characterizing the region's resource potential in the part "Population and labor resources" indicates the presence of reserves for their growth. Without high-quality labor resources, without an economically active population with a stable source of income and a decent level of income, it is impossible to achieve a high level of economic security at the meso-level.

4. Scientific, technical and innovative potential.

The Rostov Region is the largest center of science in the south of Russia, which has a powerful research base and a developed multilevel network of educational organizations providing a broad access to educational services for the population and being able to respond to economic needs in staff training and advanced staff training [35]. The educational complex of the Rostov region has more than 3,000 educational organizations of all forms, kinds and types, and is one of the largest educational complexes in the country.

Multidisciplinary and sectoral scientific institutions are actively developing in the region, a powerful sector of research and development, engaged in the production of innovative ideas and new technologies, has been formed. The region occupies a leading position in the number of researchers with academic degrees, approaches the TOP-10 subjects of Russia in the number of patent applications for inventions and the share in the total Russian volume of innovative products shipment. A network of innovation infrastructure has been developed in the region: 11 innovatively oriented educational institutions of higher education, 10 innovation and technology centers and 20 centers for collective use

All this indicates a high level of scientific, technical and innovative potential of the Rostov region, which contributes to the achievement of a high level of economic security and maintaining it at the proper level.

5. Export potential.

There are many unique enterprises of a national scale, with significant export potential in the Don region industry:

- food industry - "Aston” PLC, South Russia Group of Companies, “Agrocom” Group LLC, “Amilko” LLC and others;

- light industry - "Gloria Jeans Corporation" CJSC, "Donetsk Manufactory M" OJSC, "BTC Textile" LLC, "Alice Fashion Rus" JSC, "Merinos Carpets and Carpet Products” LLC and others;

- chemical industry - "Empils" CJSC, "Kamenskvolokno" JSC, "PCF Atlantis Pak” LLC, SRE "Kamensky Combine” and others;

- metallurgical industry - "TAGMET" PJSC, "Rostov Electrometallurgical Plant" LLC, "Isaevsky MachineBuilding Plant” LLC, “Aluminum Metallurg Rus” JSC and others;

- agricultural engineering - LLC "Combine Plant Rostselmash”, JSC “Clover”, PLC "Millerovoselmash”, LLC "Salskselmash" and others;

- Aviation industry - PJSC "Rostvertol”, PJSC “Taganrog Aviation Scientific and Technical Complex named after G.M. Beriev" and others;

- Power engineering - "Taganrog Boiler-Making Plant
Krasny Kotelshchik” OJSC, “Atommashexport” JSC, “Turbulence-DON Scientific-Production Association” LLC and others;

- production of railway rolling stock - LLC "Production Company Novocherkassk Electric Locomotive Plant”; - radio-electronic industry - JSC "Scientific-Production Enterprise of Space Instrument Making” Kvant”, PJSC "Granit”, JSC “Azov Optical and Mechanical Plant”, JSC "Taganrog Plant "Priboy”, JSC “All-Russian Scientific Research Institute "Gradient”, JSC “Taganrog Research Institute of Communications" and others.

The export development key indicators dynamics in the Rostov region indicates the positive trends in industry: in terms of total exports (in millions of US dollars), the region rose from the 17th place in the Russian Federation (2011) to 9th (2017). Despite growth, low value-added goods prevail in the export structure.

High-quality structural products and services with a high level of added value should be high-quality structural directions for the region's export potential development in the digital economy.

6 . Tourist potential.

The rich historical and cultural heritage of the region creates the basis for attracting the tourist flow. The tourist potential of the region is determined by the following groups of attractions:

- natural - specially protected natural areas;

- recreational (Starocherkassk Historical and Architectural Museum-Reserve, Archeological Museum-Reserve "Tanais", theaters and museums);

- craft (Semikarakorsk ceramics);

- gastronomic (Don crayfish, Don ear, Don kvass, Don wine, stockfish, dried fish and others).

Tourism is one of the priority sectors of the Rostov region economy, the development of which provides the opportunities for economic reproduction of the cultural, historical and natural potential of the Don region. The need to develop the existing tourism potential of the Rostov region to attract tourists has been formed up to now.

The performed analysis allows to talk about a high level of resource potential of the Rostov region. The region is able to take a leading position in various areas of economic and social development, providing a high level of economic security based on the effective use of available resources.

\section{CONCLUSION}

The regions of Russia are significantly differentiated both in terms of the resource potential development and in terms of economic security. The created situation is a consequence of differences in geographic and territorial location, the availability of natural resources, the level of the production sector development, the regional budget population, etc. The unstable socio-economic situation in Russia also plays a role, due to the foreign policy differences aggravation and artificial restrictions on the capital flows, on the one hand, and internal difficulties dictated by the infrastructure and institutional conditions imperfection, on the other hand.

The resource potential was considered as an important condition for ensuring economic security in the study. The first stage studied and systematized theoretical provisions characterizing the nature and specificity of the resource potential as a factor in ensuring economic security. On the obtained base, at the second stage, the analysis of the Rostov region economic security level was carried out and its resource potential was assessed. The analysis carried out by 
the authors allows to conclude that one of the mechanisms to increase the level of economic security at the meso-level is the effective use of the available resource potential of the territories, the choice of the most effective strategic directions and development paths. But the economic security of the state as a whole cannot be achieved in the absence of economic security of its subjects and territories. In general, theoretical and practical results of the work can be useful in managing the resource potential of the region.

\section{REFERENCES}

[1] O.V. Godina, Y.Y. Kosenkova, L.S. Maksimenko, Y.R. Mezentseva, T.A. Shcherbakova (2019) Strategic Directions of Innovational Development of SocioEconomic Systems. In: Popkova E., Ostrovskaya V. (eds) Perspectives on the Use of New Information and Communication Technology (ICT) in the Modern Economy. ISC 2017. Advances in Intelligent Systems and Computing, vol 726. Springer, Cham DOI: https://doi.org/10.1007/978-3-319-90835-9 14

[2] G.E. Krokhicheva, E. L. Arkhipov, A. S. Voskanova. The national security strategy of the Russian Federation in the system of economic security, Bulletin of Eurasian science. 2017. No.1 (38)

[3] On the Economic Security Strategy of the Russian Federation for the period up to 2030: Decree of the President of the Russian Federation dated 05.13.2017 No. 208.

http://www.consultant.ru/document/cons_doc_LAW_2166 29/1d8dcf5824d 5241136fa09b9e9c672ac5d325365

[4] V.V. Kayukov, A.P. Shikhverdiev. Institutional characteristics of the economic security of a region, Regional Economy. - 2018. Vol. 14. No. 4. pp. 1181-1193. DOI: https://doi.org/10.17059/2018-4-10

[5] A.G. Svetlakov, I.M. Swallow The influence of the information space on the economic security of the region, Economy of the region. - 2018. Vol. 14. No. 2. pp. 474484 DOI: https://doi.org/10.17059/2018-2-11

[6] V.A. Tsvetkov, M.N. Dudin, N.V. Lyasnikov. Analytical approaches and methods for assessing the economic security of a region, Regional Economy. - 2019. Vol. 15. No. 1. pp. 1-12. DOI: https://doi.org/10.17059/2019-1-1

[7] C.V. Novoselov, S.A. Panikhidnikov. Systematic assessment of the economic security of the region, Coal. 2018. No. 12 (1113)

https://cyberleninka.ru/article/n/sistemnaya-otsenkaekonomicheskoy-bezopasnosti-regiona (accessed: 02/11/2020) DOI: http://dx.doi.org/ 10.18796 / 0041-57902018-12-48-53

[8] D.V. Valko. Economic security: the essence and current approaches to definition: materials of the IX
International scientific-practical conference "Innovative development of the Russian economy”. M. Publishing house of Russian University of economics named after G.V. Plekhanov, 2016. pp. 222-225

[9] On the national goals and strategic objectives of the development of the Russian Federation for the period until 2024: Decree of the President of the Russian Federation of 05.05.2018 No. 204

http://www.consultant.ru/document/cons_doc_LAW_2974 32

[10] E.V. Mikhalkina, N.A. Kosolapova. Assessment of the intangible resources potential use of the region, Space of Economics. 2018. No1

https://cyberleninka.ru/article/n/otsenka-ispolzovaniyapotentsiala-nematerialnyh-resursov-regiona (accessed 05.02.2020) DOI: https://doi.org/10.23683/2073 -66062018-16-1-118-133

[11] G.E. Krokhicheva, V.V. Lesnyak, E.M. Selezneva, E.S. Arakelyants. Adaptive engineering management tools of enterprise economic security, in: Management Science Letters, vol. 8, issue 6, 2018, pp. 605-618. DOI: https://doi.org/10.5267/j.msl.2018.4.030

[12] A large encyclopedic dictionary http://encdic.com/enc_big/Process-48657.html

[13] T.L. Sergeeva L.E. Skripkina. Methodological approaches to the study of the resource potential of the region, Bulletin of Novgorod State University. 2015. No. 87, part 2. pp. 97-100

[14] E.A. Bessonova, O.Yu. Mereshchenko. Methodological approaches to assessing the resource potential of the region, Questions of the regional economy. 2016.Vol. 29. No. 4. pp. 17-24

[15] E.A. Dynnikov, A.N. Milyukin. Methodological approaches to assessing the resource potential of the region, Actual problems of the economy in the context of the reform of modern society. Materials of the IV International Scientific and Practical Conference dedicated to the 140th anniversary of the founding of Belgorod State University. 2016. pp. 95-98

[16] G.E. Mekush, E.O. Ushakova. The study of the resource potential of the Novosibirsk region for the development of the tourism industry, Bulletin of SSUGT (Siberian State University of Geosystems and Technologies). 2015. No. 1 (29) https://cyberleninka.ru/article/n/issledovanie-resursnogopotentsiala-novosibirskoy-oblasti-dlya-razvitiyaturistskoy-otrasli

[17] S.S. Galazova, T.G. Krasnova, T.N. Plotnikova. Assessment of the resource potential of the social and innovative development of the federal district, Corporate Governance and Innovative Development of the North 
state programs in the Rostov region based on the results of 2018 https://www.donland.ru/result-report/406

Law, Management and Venture Investment of Syktyvkar State University. 2016. No. 4. P.108

https://elibrary.ru/item.asp?id=28379745

[18] O.A. Lomovtseva. The total resource potential of the region: a methodology for determining and measuring, Scientific reports of Belgorod State University. Series: Economics. Computer science. 2012. No. 1-1 (120) https://cyberleninka.ru/article/n/sovokupnyy-resursnyypotentsial-regiona-metodologiya-opredeleniya-iizmereniya

[19] Yu.V. Markina. Resource potential of innovative development of the regional economy, Herald of the South-Ural University of Economy, Management and Law. 2011. No. 5.

https://cyberleninka.ru/article/n/resursnyy-potentsialinnovatsionnogo-razvitiya-ekonomiki-regiona

[20] A.A. Roshchupkina, T.V. Sidorina. The system of regional indicators of economic security, Bulletin of Eurasian science. 2019. No3

https://cyberleninka.ru/article/n/sistema-regionalnyhpokazateley-ekonomicheskoy-bezopasnosti

[21] V.V. Gorokhnaya, A.G. Druzhinin. Indication of economic security of the border region in the conditions of geoeconomic turbulence (on the example of the Rostov region), State and municipal administration. Scholarly notes of SKAGS. 2019. No. 1

https://cyberleninka.ru/article/n/indikatsiya-

ekonomicheskoy-bezopasnosti-prigranichnogo-regiona-vusloviyah-geoekonomicheskoy-turbulentnosti-na-primererostovskoy

[22] I.V. Novikova, N.I. Krasnikov. Indicators of the region's economic security, Economics. - 2009. - No. 11. Pp. 132-138

[23] V.P. Chichkanov, L.A. Belyaevskaya-Plotnik. Analysis of approaches to assessing regional processes of the formation of socio-economic security, Regional Economy. 2016. No. 3

[24] M.V. Bugaev, N.V. Morozova, A.A. Hatko. The state of the level of economic security of the regions on the example of the Rostov region, Scientific and methodological electronic journal "Concept". - 2017. Vol. 24. pp. 19-24 http://e-koncept.ru/2017/770451.html

[25] Rostov region in numbers. Brief statistical compilation Federal State Statistics Service. Rostovstat. Rostov-on-Don, 2019

https://rostov.gks.ru/storage/mediabank/maket!2018.pdf

[26] Consolidated annual report on the progress of implementation and on evaluating the effectiveness of
[27] Socio-economic situation in the Rostov region according to the results of 2018 https:

//www.donland.ru/result-report/198

[28] T.A. Makarenya, A.V. Kulikova. Analysis of the main trends and prospects for the development of industry in the Rostov region, Regional Economics: theory and practice. 2018. No1 (448)

https://cyberleninka.ru/article/n/analiz-osnovnyhtendentsiy-i-perspektivy-razvitiya-promyshlennostirostovskoy-oblasti

[29] Strategy for the socio-economic development of the Rostov Region for the period until 2030: Decree of the Government of the Rostov Region dated December 26, 2018 No. 864 https://www.donland.ru/documents/119

[30] Investment development strategy of the Rostov region until 2030: Decree of the Rostov region Government of July 31, 2013 No. 474

https://www.donland.ru/activity/1192

[31] State program of the Rostov Region "Economic Development and Innovation Economics": Decree of the Rostov Region Government dated 10/15/2018 No. 637 URL: https://www.donland.ru/activity/1290

[32] Yu.R. Mezentseva, E.A. Gurtovaya, V.A. Popravkina. Analysis of the unemployment rate in the Russian Federation and regions for 2012-2017: materials of the scientific-practical conference "Actual issues of ensuring economic security in the Russian Federation in the digital economy”. Melbourne, 2018

[33] Yu.R. Mezentseva, D.I. Smolyakova. Migration as one of the economic security elements of the Russian Federation: materials of the scientific-practical conference "Actual issues of ensuring economic security in the Russian Federation in the digital economy”. Melbourne, 2018

[34] Yu.R. Mezentseva A.M. Bokova, M.N. Pogorelov. The role of human capital in the economic security of the Russian Federation: materials of the scientific-practical conference "Actual issues of ensuring economic security in the Russian Federation in the digital economy". Melbourne, 2018

[35] E.A. Dalchenko, V.V. Kuznetsova, A.N. Shilina. Digitalization of the regional economy: development priorities and information security factors (based on materials from the Rostov region) // RPPE. 2019. No. 3 (101) https://cyberleninka.ru/article/n/tsifrovizatsiyaregionalnoy-ekonomiki-prioritety-razvitiya-i-faktoryinformatsionnoy-bezopasnosti-na-materialah-rostovskoyoblast 